\title{
PENGARUH MEDIA KULTIVASI Chaetoceros gracilis TERHADAP KANDUNGAN KIMIAWI DAN POTENSI INHIBITOR PROTEASE
}

\author{
[Effect of Chaetoceros gracilis Cultivation Media to the Chemical Content and Protease Inhibitor Potential]
}

\author{
Iriani Setyaningsih*, Tati Nurhayati dan Uzainah Aremhas \\ Departemen Teknologi Hasil Perairan, Fakultas Perikanan dan IImu Kelautan, Institut Pertanian Bogor, Bogor
}

Diterima 28 Januari 2013 / Disetujui 09 Januari 2014

\begin{abstract}
Microalgae produce secondary metabolites with different characteristics for each genus, species or strain. A single species of microalgae can produce several bioactive compounds, including protease inhibitors which can prevent deterioration of fish. In this study, we observed the growth of Chaetoceros gracilis in the media NPSi and NPSi + NaHCO3 and determined the chemical content and the potency of protease inhibitor from Chaetoceros gracilis in both media. The culture was harvested at 8 and 15 days. Screening of protease inhibitor activity was performed by agar diffusion method. Protease inhibitor activity was tested on three pathogenic protease-producing bacteria, namely Staphylococcus aureus, Bacillus cereus and Escherichia coli. The pathogenic bacteria often contaminate foodstuffs. The results showed that media NPSi and NPSi + NaHCO3 affected protein and lipid content of $\mathrm{C}$. gracilis, but the culture age did not affect them. The protein content of $\mathrm{C}$. gracilis cultivated in NPSi media (34.75 and 32.94\%) was higher than in NPSi + NaHCO3 media (28.13 and 27.13\%), while the lipid content was 16.36 and 18.06, 23.86 and $25.40 \%$ respectively. Extracts of $\mathrm{C}$. gracilis grown in NPSi and NPSi+NaHCO3 media had inhibitory activity against the test bacteria. Inhibitory activity against $E$. coli was greater than $S$. aureus and $B$. cereus.
\end{abstract}

Keywords: Bacillus cereus, Chaetoceros gracilis, chemical content, Escherichia coli, protease inhibitor, Staphylococcus aureus

\begin{abstract}
ABSTRAK
Mikroalga menghasilkan metabolit sekunder dengan karakteristik yang berbeda untuk setiap genus, spesies atau strain. Satu spesies mikroalga dapat memiliki beberapa potensi dari senyawa bioaktifnya, termasuk inhibitor protease. Inhibitor protease dapat menghambat kemunduran mutu ikan. Pada penelitian ini diketahui pertumbuhan Chaetoceros gracilis dalam media NPSi (Nitrogen, Phosphor, Silika) dan NPSi ditambah $\mathrm{NaHCO}_{3}$, serta ditentukan kandungan kimiawi dan potensi inhibitor protease Chaetoceros gracilis dalam kedua media tersebut. Kultur dipanen pada umur kultur 8 dan 15 hari. Penapisan aktivitas inhibitor protease dilakukan dengan metode difusi agar. Aktivitas inhibitor protease diujikan pada tiga bakteri patogen penghasil protease, yaitu Staphylococcus aureus, Bacillus cereus dan Escherichia coli. Bakteri patogen tersebut sering mengontaminasi bahan pangan. Hasil yang diperoleh menunjukkan bahwa media NPSi dan NPSi ditambah $\mathrm{NaHCO}_{3}$ mempengaruhi perbedaan kandungan protein dan lipid C. gracilis, namun umur kultur tidak mempengaruhinya. Kadar protein C. gracilis dalam media NPSi (34.75 dan 32.94\%) lebih tinggi dibanding dalam media NPSi ditambah $\mathrm{NaHCO}_{3}$ (28.13 dan 27.13\%), sedangkan kadar lipidnya berturut-turut 16.36 dan 18.06, serta 23.86 dan $25.40 \%$. Ekstrak dari $C$. gracilis yang dikultivasi dalam kedua media tersebut memiliki aktivitas inhibitor protease yang sama terhadap E. coli. Aktivitas hambatan terhadap E. coli lebih besar dibandingkan terhadap S. aureus dan B. cereus.
\end{abstract}

Kata kunci: Bacilluscereus, Chaetoceros gracilis, Escherichia coli, inhibitor protease, kandungan kimiawi, Staphylococcus aureus

\section{PENDAHULUAN}

Mikroalga memiliki banyak keunggulan, antara lain mengandung protein dan asam lemak tidak jenuh tinggi. Pemanfaatan mikroalga masih terbatas sebagai pakan dan pangan. Selain itu mikroalga juga dapat dimanfaatkan sebagai bahan dasar obatobatan atau farmasi. Jenis mikroalga yang banyak ditemui di perairan pantai Indonesia antara lain Chaetoceros gracilis yang berwarna kuning kecoklatan sehingga sering disebut dengan golden-brown algae.

Pemanfaatan C. gracilis saat ini masih terbatas sebagai pakan dalam budidaya udang. Chaetoceros gracilis memilik kandungan lipid yang cukup tinggi $\pm 28 \%$ (Elias et al. 2005).

*Penulis Korespondensi:

E-mail: iriani25@gmail.com
Selama pertumbuhan Chaetoceros gracilis, kandungan asam lemak golongan SAFA menurun $(29.53 \%)$ dari fase akhir eksponensial sampai stasioner dan meningkat lagi pada fase kematian (47.38\%). Namun asam lemak golongan PUFA meningkat dari fase akhir eksponensial sampai stasioner. Asam oleat ditemukan pada semua tahap pertumbuhan dengan konsentrasi $17-21 \%$ dari total asam lemak (Pratiwi et al. 2009). Kandungan lipid ini membuat Chaetoceros potensial sebagai penghasil biofuel. Selain komponen kimia, Chaetoceros juga mempunyai komponen aktif. Hasil penelitian Setyaningsih et al. (2008) menunjukkan bahwa C. gracilis memiliki aktivitas antibakteri yang dapat menghambat pertumbuhan bakteri patogen Staphylococcus aureus, Bacillus cereus, Vibrio harveyi, dan Escherichia coli.

Mikroalga menghasilkan metabolit sekunder yang penyebarannya terbatas dan memiliki karakteristik yang berbeda 
untuk setiap genus, spesies atau strain tertentu, sehingga tidak mengherankan jika satu spesies mikroalga memiliki beberapa potensi dari senyawa bioaktifnya. Oleh karena itu perlu dilakukan penelitian mengenai potensi lain dari C. gracilis, yaitu sebagai inhibitor protease.

Inhibitor protease adalah senyawa yang dapat mengganggu aktifitas enzim protease dengan mengganggu kerja sel penghasil protease (Lehninger, 2005). Enzim protease atau proteolitik adalah enzim yang bekerja sebagai katalis dalam reaksi hidrolisis protein. Beberapa bakteri patogen memilik enzim protease ekstraseluler (pemecah protein) untuk merusak jaringan sel inangnya seperti Bacillus dan E. coli. Penyakit seperti HIV dan kanker sangat erat hubungannya dengan enzim protease (Hui, 2003). Keterlibatan enzim protease dalam mekanisme patogenesis meningkatkan perhatian penelitian untuk mendapatkan senyawa obat yang dapat menghambat enzim protease. Inhibitor protease juga berperanan dalam pengolahan pangan, salah satunya dapat menghambat kemunduran mutu hasil perikanan. Hasil penelitian Nurhayati et al. (2011) menunjukkan bahwa perendaman dengan inhibitor katepsin dapat memperpanjang fase postrigor ikan bandeng sebanyak 72 jam atau 3 hari lebih lama dibanding ikan bandeng kontrol. Beberapa inhibitor protease alami dapat dihasilkan dari hasil perikanan seperti sponge, ikan, telur ikan, telur, kentang. Masing-masing senyawa yang dihasilkan berbeda jenis dan potensi aktivitasnya. Pada penelitian ini dianalisis potensi mikroalga $C$. gracilis sebagai inhibitor protease.

Mikroalga dalam pertumbuhannya dipengaruhi oleh beberapa faktor antara lain nutrien, suhu, intensitas cahaya, umur dan sebagainya. Nutrien dapat mempengaruhi komposisi kimia seperti protein, lemak, karbohidrat mikroalga selama pertumbuhan. Saavedra dan Voltolina (2006) menyatakan bahwa kandungan protein selama pertumbuhan mikroalga menurun hingga akhir fase pertumbuhan.

Keberadaan sumber karbon dalam media juga dapat mempengaruhi pertumbuhan mikroalga. Sumber karbon dalam media kultur dapat diperoleh dari udara yang diberikan melalui aerasi. Tersedianya $\mathrm{CO}_{2}$ di dalam media kultur merupakan faktor penting karena secara langsung dipakai sebagai bahan untuk membentuk molekul-molekul organik melalui proses fotosintesis. Karbondioksida adalah sumber karbon yang lebih disukai oleh tumbuhan akuatik seperti alga dibandingkan karbonat atau bikarbonat. Pada penelitian ini digunakan $\mathrm{NaHCO}_{3}$ untuk memperbanyak ketersediaan sumber karbon. Pada penelitian ini mikroalga Chaetoceros gracilis dikultivasi dalam media NPSi dan media NPSi yang ditambahkan $\mathrm{NaHCO}_{3}$, sebagai sumber karbon. Kultivasi dilakukan di luar ruangan dengan memanfaatkan sinar matahari sebagai sumber cahaya. Menurut Voltolina et al. (2007) cahaya, temperatur, dan komposisi media akan memodifikasi fisiologis, pertumbuhan, dan aktivitas metabolisme mikroalga.

Penelitian ini bertujuan melihat pertumbuhan C. gracilis dalam media NPSi dan NPSi $+\mathrm{NaHCO}_{3}$, menentukan komposisi kimia khususnya protein dan lipiddari $C$. gracilis pada umur berbeda. Selain itu juga mengetahui potensi $C$. gracilis sebagai inhibitor protease, yang selama ini belum ada.

\section{BAHAN DAN METODE}

\section{Bahan}

Mikroalga Chaetoceros gracilis diperoleh dari Pusat Penelitian dan Pengembangan Oseanografi LIPI Jakarta. Bakteri uji yang digunakan meliputi Staphylococcus aureus, air laut untuk media dibeli dari toko akuarium di Bogor, Bacillus cereus dan Escherichia coli yang diperoleh dari Fakultas Kedokteran Hewan, IPB.

\section{Kultivasi Chaetoceros gracilis}

Proses kultivasi untuk memperoleh kurva pertumbuhan $C$. gracilis dilakukan menggunakan tabung kultur transparan dengan volume kultur $2 \mathrm{~L}$. Perbandingan bibit $\mathrm{C}$. gracilis dengan air laut yang digunakan adalah 1:10 (v/v). Media yang digunakan adalah media NPSi dan NPSi+NaHCO $3(0.5 \mathrm{~g} / \mathrm{L})$. Media NPSi terdiri atas urea (Petrokimia) sebagai sumber nitrogen, Super Phosphat (Petrokimia) sebagai sumber fosfat dan natrium silikat (dibeli di toko kimia Bogor) sebagai sumber silika. Selanjutnya aerator dipasang dan dinyalakan non stop. Sumber cahaya berasal dari sinar matahari. Penghitungan jumlah sel menggunakan mikroskop dan haemocytometer (Marienfeld) dilakukan setiap hari untuk memperoleh kurva pertumbuhan $C$. gracilis.

Setelah diperoleh kurva pertumbuhan, selanjutnya dilakukan kultivasi $C$. gracilis dalam skala besar (14 L) untuk memperoleh biomassa sel $C$. gracilis lebih banyak. Kultur dipanen pada akhir fase log dan pertengahan fase stasioner. Biomassa C. gracilis dipisahkan dari media (cairan) dengan sistem filtrasi menggunakan filter keramik. Biomassa $C$. gracilis yang didapat kemudian dikeringkan menggunakan freeze dryer (Yamato), selanjutnya ditimbang untuk diketahui berat keringnya yang akan digunakan untuk tahapan penelitian selanjutnya.

\section{Ekstraksi senyawa aktif dari C. gracilis}

Proses ekstraksi didahului dengan pemecahan sel terhadap biomasa sel $C$. gracilis kering menggunakan glass bead dengan prinsip bead milling. Biomassa yang sudah diperoleh dimasukkan ke dalam tabung reaksi dan ditambah etanol (Merck) sebanyak $5 \mathrm{~mL}$ lalu dilakukan pemecahan sel dengan glass bead selama 10 menit. Selanjutnya dilakukan ekstraksi menggunakan pelarut etanol (1:25) dengan metode maserasi $(3 \times 24$ jam). Pemisahan filtrat dilakukan menggunakan metode penyaringan, selanjutnya dievaporasi, sehingga diperoleh ekstrak kasar yang digunakan untuk uji inhibitor protease.

\section{Analisis kandungan kimiawi}

Analisis kandungan kimiawi dilakukan terhadap kandungan protein dan lemak biomasa sel $C$. gracilis. Untuk analisis protein mengacu metode Lowry, sedangkan analisis lipid menggunakan metode Bligh dan Dyer (Iverson et al. 2001).

\section{Analisis protein}

Analisis protein dilakukan dengan menimbang $4 \mathrm{mg}$ biomassa kering Chaetoceros kemudian disuspensikan dalam $20 \mathrm{~mL}$ akuades dan dihomogenkan. Kemudian sampel dan bovine serum albumin (BSA) dipipet masing-masing $2 \mathrm{~mL}$ ke tabung sentrifuse. Setelah itu ditambahkan $5 \mathrm{~mL}$ pereaksi Lowry ke dalam sampel dan BSA lalu dihomogenkan. Sampel dan 
BSA didiamkan selama satu jam. Kemudian masing-masing ditambahkan dua kali $0.3 \mathrm{~mL}$ folin ciocalteau phenol (Merck) tetes demi tetes dan dihomogenkan kembali serta didiamkan 15 menit. Setelah itu sampel dan BSA disentrifugasi menggunakan sentrifus (Hettich universal) dengan kecepatan 3000 rpm selama 15 menit. Selanjutnya supernatan diukur absorbansinya dengan spektro-fotometer (Spektronic UV-VIS A 5000) panjang gelombang $660 \mathrm{~nm}$ dan didapat kurva standar. Kandungan persen protein dalam C. gracilis dapat dihitung dengan menggunakan kurva standar.

\section{Analisis lipid}

Biomasa C. gracilis diekstrak dengan menambahkan $5 \mathrm{~mL}$ kloroform (Merck), metanol (Merck), dan air non ion (FKH) dengan perbandingan 5:10:4 selanjutnya sampel disentrifugasi dengan kecepatan $2500 \mathrm{rpm}$ selama 10 menit. Supernatan yang terbentuk dipindahkan ke dalam tabung sentrifuse lain dan ditambahkan kloroform, metanol, dan air dengan perbandingan 5:10:4 hingga volume menjadi $5.7 \mathrm{~mL}$. Kemudian sampel ditambahkan $1.5 \mathrm{~mL}$ kloroform dan $1.5 \mathrm{~mL}$ air non ion dan disentrifuse kembali dengan kecepatan 2500 rpm selama 10 menit. Hasil sentrifuse akan terbentuk lapisan lipid dan pelarut. Lapisan lipid yang berwarna hijau dipipet dan dipindahkan ke dalam botol vial yang telah ditimbang beratnya terlebih dahulu. Kemudian dilakukan peniupan dengan gas $\mathrm{N}_{2}$ sampai larutan kloroform menguap, lalu botol tersebut ditimbang sebagai berat akhir botol untuk mengetahui berat total lipid. Rumus perhitungan lipid total adalah sebagai berikut:

Total lipid $=$ berat akhir botol - berat awal botol

\section{Pengujian ekstrak C. gracilis sebagai inhibitor protease (Nurhayati et al. 2004)}

Proses pengujian ini bertujuan untuk mengetahui potensi ekstrak C. gracilis sebagai inhibitor protease. Media yang digunakan adalah media Luria Agar, Sigma-Aldrich (LA) skim $2 \%$. Keempat ekstrak yang diperoleh dari kultur $C$. gracilis $(C$. gracilis yang dikultivasi dalam medium NPSi dipanen pada kultur umur 8 dan 15 hari serta $C$. gracilis yang dikultivasi dalam medium NPSi+NaHCO ${ }_{3}$ dipanen pada kultur umur 8 dan 15 hari) selanjutnya disuspensikan dalam etanol sehingga konsentrasinya $10 \%(\mathrm{~b} / \mathrm{v})$. Sebanyak $200 \mu \mathrm{L}$ dimasukkan ke dalam cawan Petri, kemudian sebanyak $10 \mathrm{~mL}$ LA skim 2\% ditambahkan ke dalam cawan petri steril tersebut dan diputar atau digoyang hingga homogen dan dibiarkan hingga membeku. Untuk kontrol digunakan $200 \mu \mathrm{L}$ etanol dan media LA skim $2 \%$ cair. Bakteri uji (Staphylococcus aureus, Bacillus cereus dan Escherichia coli) diambil satu ose kemudian ditusukkan ke dalam media yang telah beku. Selanjutnya diinkubasi selama 24 jam pada suhu $37^{\circ} \mathrm{C}$. Zona bening yang terbentuk diukur menggunakan jangka sorong dan dihitung indeks proteolitik masingmasing bakteri baik dalam medium kontrol maupun medium yang mengandung ekstrak dengan menggunakan rumus:

$$
\text { Indeks Proteolitik (IP) }=\frac{a}{b}
$$

Keterangan:

$\mathrm{a}=$ diameter zona bening $(\mathrm{mm})$

$\mathrm{b}=$ diameter koloni $(\mathrm{mm})$
Daya hambat ekstrak C. gracilis terhadap enzim protease bakteri dihitung dengan menggunakan rumus:

Potensi Daya Hambat $=\left[1-\left[\frac{\mathrm{Pe}}{\mathrm{IPK}}\right]\right] \times 100 \%$

Keterangan:

$\mathrm{IPe}=$ Indeks proteolitik bakteri uji pada media mengandung ekstrak IPk = Indeks proteolitik bakteri uji pada media kontrol

\section{HASIL DAN PEMBAHASAN}

\section{Kurva pertumbuhan Chaetoceros gracilis}

Kurva pertumbuhan $C$. gracilis yang dikultivasi dalam medium NPSi mengalami fase lag pada $\mathrm{H}-0$ sampai dengan $\mathrm{H}-1$ (Gambar 1), sedangkan yang dikultivasi dalam medium $\mathrm{NPSi}+\mathrm{NaHCO}_{3}$ tidak mengalami fase lag (Gambar 2). Hal ini dapat terjadi karena fase lag berjalan cepat, sesaat sebelum fase log, sehingga yang nampak pada kurva hanyalah fase log (Richmond, 2004). Fase log terjadi pada H-1 sampai H-6 untuk C. gracilis yang dikultivasi dalam medium NPSi dan $\mathrm{H}-0$ sampai $\mathrm{H}-4$ untuk $\mathrm{C}$. gracilis yang dikultivasi dalam medium $\mathrm{NPSi}+\mathrm{NaHCO}_{3}$. Fase pertumbuhan $\mathrm{C}$. gracilis yang selanjutnya adalah fase stasioner yang terjadi pada $\mathrm{H}-6$ sampai $\mathrm{H}-30$ untuk kultivasi dalam medium NPSi dan terjadi pada $\mathrm{H}-4$ sampai dengan $\mathrm{H}-2 \mathrm{O}$ untuk kultivasi dalam medium $\mathrm{NPSi}+\mathrm{NaHCO}_{3}$ Fase pertumbuhan berikutnya adalah fase kematian mulai terjadi pada hari ke-31 untuk kultivasi dengan media NPSi dan terjadi pada hari ke-21 untuk kultivasi dengan media $\mathrm{NPSi}+\mathrm{NaHCO}_{3}$

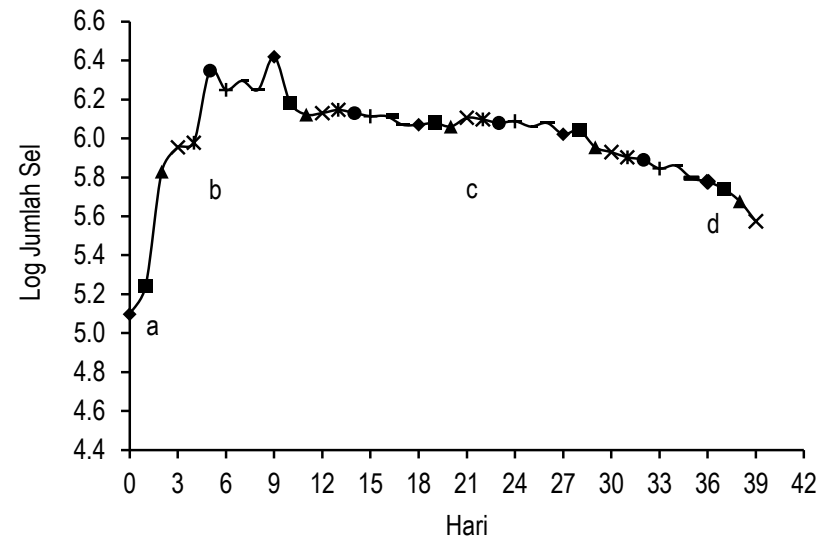

Gambar 1. Kurva kehidupan Chaetoceros gracilis dalam media NPSi ( $a$ =fase lag, $b$ =fase $\log , c=$ fase stasioner dan $d$ =fase kematian)

Chaetoceros gracilis yang dikultivasi dalam medium NPSi memiliki kurva pertumbuhan yang lebih panjang serta kepadatan sel yang lebih tinggi dibandingkan $C$. gracilis yang dikultivasi dalam medium NPSi+NaHCO 3 . Komposisi kimia yang berbeda dan perubahan kondisi lingkungan memberikan pengaruh terhadap metabolisme sel mikroalga (Voltolina et al. 2007). Penambahan $\mathrm{NaHCO}_{3}$ pada awalnya meningkatkan kepadatan sel, namun seiring berjalannya waktu kultivasi terjadi perubahan kondisi lingkungan kultur, perubahan kondisi lingkungan memberikan pengaruh terhadap metabolisme sel mikroalga, 
sehingga jumlah karbon yang berlebihan dari penambahan $\mathrm{NaHCO}_{3}$ menyebabkan autoinhibition.

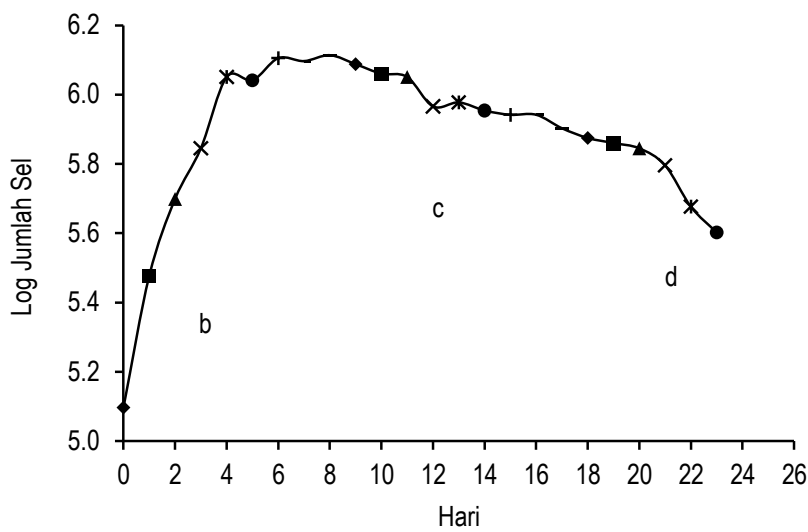

Gambar 2. Kurva kehidupan Chaetoceros gracilis dalam media $\mathrm{NPSi}+\mathrm{NaHCO}_{3}$ ( $b$ =fase log, $c$ =fase stasioner dan $d=$ fase kematian)

\section{Komposisi kimia biomasa C. gracilis}

Kandungan protein $C$. gracilis yang dikultivasi dalam medium NPSi dipanen pada umur 8 dan 15 hari sebesar 34.75 dan $32.94 \%$, sedangkan yang dikultivasi dalam medium $\mathrm{NPSi}+\mathrm{NaHCO}_{3}$ dipanen pada umur 8 dan 15 hari sebesar 28.13 dan $27.13 \%$. Kandungan lipid $C$. gracilis yang dikultivasi dalam medium NPSi umur panen 8 dan 15 hari adalah 16.36 dan $18.06 \%$, sedangkan yang dikultivasi dalam medium NPSi $+\mathrm{NaHCO}_{3}$ umur panen 8 dan 15 hari adalah 23.86 dan $25.40 \%$ (Gambar 3).

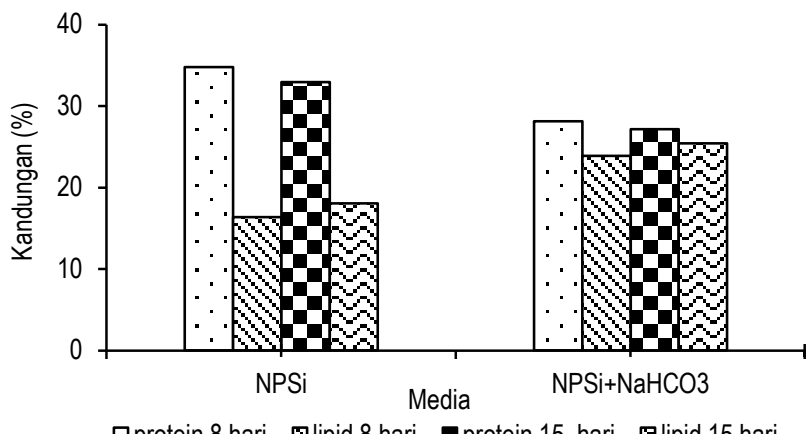

Gambar 3. Kandungan lipid dan protein Chaetoceros gracilis pada umur panen 8 dan 15 hari

Media NPSi dan NPSi $+\mathrm{NaHCO}_{3}$ mempengaruhi perbedaan kandungan protein dan lipid $\mathrm{C}$. gracilis, sedangkan umur kultur tidak mempengaruhi. Kadar protein $C$. gracilis dalam media NPSi lebih tinggi dibanding dalam media NPSi $+\mathrm{NaHCO}_{3}$. Hal ini sesuai dengan laju pertumbuhan $C$. gracilis dalam media tersebut. Laju pertumbuhan $C$. gracilis yang dikultivasi dalam media NPSi pada hari ke-8 adalah 0.332 pembelahan sel/hari, sedangkan yang dikultivasi dalam media $\mathrm{NPSi}+\mathrm{NaHCO}_{3}$ adalah 0.293 pembelahan sel/hari. Laju pertumbuhan $C$. gracilis yang dikultivasi dalam media NPSi lebih tinggi dibandingkan $C$ gracilis yang dikultivasi dalam medium NPSi+NaHCO3. Hal ini dapat terjadi karena penambahan $\mathrm{NaHCO}_{3}$ yang berlebihan menjadi autoinhibition atau penghambat pertumbuhan.
Richmond (2004) menyatakan bahwa karbon selama fase log diutamakan untuk sintesis protein. Hal ini disebabkan mikroalga cenderung mensintesis struktur fungsional terlebih dahulu untuk bereplikasi dan tumbuh.

Selain faktor nutrisi, meningkatnya kandungan lipid juga dipengaruhi oleh fisiologis $C$. gracilis. Sel C. gracilis cenderung mensintesis lipid pada fase stasioner sebagai cadangan energi untuk mempertahankan kelangsungan hidupnya karena laju pertumbuhan sel telah menurun.

\section{Potensi inhibitor protease dari C. gracilis}

Pengujian inhibitor protease ini bertujuan untuk mengetahui potensi inhibitor protease dari $C$. gracilis dengan mengukur daya hambat ekstrak $C$. gracilis terhadap enzim protease bakteri uji yang ditandai dengan mengecilnya atau tidak terbentuknya zona bening di sekeliling koloni bakteri. Zona bening yang terbentuk pada media kontrol menunjukkan indeks proteolitik bakteri uji. Indeks proteolitik disajikan pada Gambar 4 , sedangkan daya hambat ekstrak $C$. gracilis terhadap enzim protease disajikan pada Tabel 1 .

Ekstrak C. gracilis yang memiliki aktivitas terbaik dalam menghambat enzim protease $S$. aureus, yaitu ekstrak $C$. gracilis yang ditumbuhkan dalam media NPSi umur panen 15 hari, yaitu sebesar $40.17 \%$.

Tabel 1. Daya hambat ekstrak Chaetoceros gracilis terhadap enzim protease bakteri patogen

\begin{tabular}{cccc}
\hline \multirow{2}{*}{$\begin{array}{c}\text { Ekstrak } \\
\text { Chaetoceros gracilis }\end{array}$} & \multicolumn{3}{c}{ Daya Hambat terhadap Bakteri Uji (\%) } \\
\cline { 2 - 4 } & $\begin{array}{c}\text { Staphylococcu } \\
\text { s aureus }\end{array}$ & $\begin{array}{c}\text { Bacillus } \\
\text { cereus }\end{array}$ & $\begin{array}{c}\text { Escherichia } \\
\text { coli }\end{array}$ \\
\hline A & 39.8 & 37.78 & 100 \\
B & 40.17 & 34.92 & 64.67 \\
C & 15.18 & 40.08 & 100 \\
D & 32.14 & 17.14 & 66 \\
\hline
\end{tabular}

Keterangan: $C$. gracilis yang dikultivasi pada $(A)$ media NPSi panen 8 hari, $(B)$ media NPSi panen 15 hari, $(\mathrm{C})$ media NPSi+NaHCO 3 panen 8 hari, (D) media $\mathrm{NPSi}+\mathrm{NaHCO}_{3}$ panen 15 hari

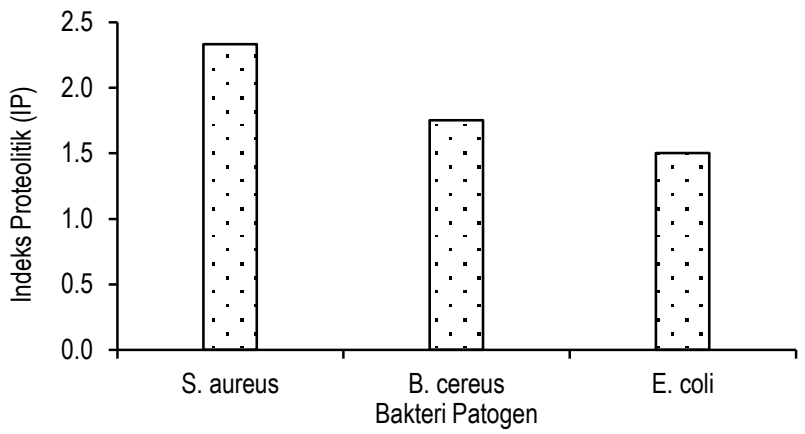

Gambar 4. Indeks proteolitik bakteri patogen yang didasarkan pada diameter zona bening terhadap diameter koloni bakteri

Indeks proteolitik (IP) merupakan nilai yang menunjukkan kemampuan bakteri patogen memproduksi enzim protease secara ekstra seluler. Hasil penelitian memperoleh nilai IP dari Staphylococcus aureus (S. aureus), Bacillus cereus (B. cereus) dan Escherichia coli ( $E$. coli) masing-masing adalah 2.33; 1.75 dan 1.5. Kemampuan memecah protein ini dapat terlihat dari terbentuknya zona bening di sekitar koloni. 
Hasil uji aktivitas inhibitor protease menunjukkan bahwa ekstrak C. gracilis yang dikultivasi dalam media NPSi dan $\mathrm{NPSi}+\mathrm{NaHCO}_{3}$ memiliki aktivitas inhibitor protease terhadap bakteri uji Staphylococcus aureus, Bacillus cereus dan Escherichia coli. Daya hambat ekstrak terhadap bakteri uji tidak sama, karena setiap bakteri mempunyai sensitivitas terhadap komponen aktif yang berbeda. Secara umum ekstrak dari $C$. gracilis yang ditumbuhkan dalam media NPSi dan $\mathrm{NPSi}+\mathrm{NaHCO}_{3}$ tidak menunjukkan perbedaan aktivitas inhibitor protease yang terlalu besar. Hal ini sesuai dengan pola pertumbuhan C. gracilis dalam kedua media yang digunakan juga tidak menunjukkan perbedaan. Penambahan $\mathrm{NaHCO}_{3}$ tidak terlalu mempengaruhi komponen aktif yang diduga berperan sebagai inhibitor protease.

Daya hambat ekstrak terhadap S. Aureus lebih kecil dibandingkan E. coli. Hal ini diduga S. Aureus menghasilkan aureocin yang merupakan protease yang stabil. Staphylococcus aureus merupakan bakteri Gram positif dan memiliki struktur kristal protein yang melindungi serin proteasenya. Antara substrat dengan sisi aktif protease membentuk ikatan hidrofobik yang lengkap membentuk rantai polar pada sisi aktifnya (Popowicz et al. 2006). Kestabilan, kristal pelindung protease dan ikatan enzim-substrat yang kuat diduga membuat ekstrak C. gracilis sulit untuk menghambat enzim proteasenya. Pengujian terhadap $B$. cereus menunjukkan bahwa ekstrak $C$. gracilis memiliki aktivitas inhibitor protease lebih kecil dibanding terhadap E. coli. Nasaimento dan Martins (2004) melaporkan bahwa enzim protease Bacillus bersifat stabil pada suhu tinggi $30-60^{\circ} \mathrm{C}$ dan aktivitas proteolitiknya dapat bekerja pada kisaran $\mathrm{pH}$ yang panjang yaitu 6 sampai 8.5. Kestabilan enzim protease $B$. cereus membuat aktivitasnya sulit dihambat oleh ekstrak.

Ekstrak C. gracilis dapat menghambat enzim protease $E$. coli dengan baik. Media pertumbuhan $C$. gracilis yang digunakan tidak mempengaruhi aktivitas inhibitor protease terhadap $E$. coli. Ekstrak C. gracilis yang ditumbuhkan dalam media NPSi dan media NPSi+NaHCO ${ }_{3}$ dipanen pada umur 8 hari mampu menghambat enzim protease $E$. coli secara sempurna (100\%). Hal ini diduga ekstrak C. gracilis mampu berikatan dengan substrat sehingga menghambat produksi enzim protease dan proses proteolisis. Aktivitas hambatan terhadap E. coli lebih besar dibandingkan $S$. aureus dan $B$. cereus. Aktifitas inhibitor protease dari setiap biota tidak sama. Hal ini berkaitan dengan komponen aktif yang dihasilkan. Nurhayati et al. (2004) melaporkan bahwa hasil penapisan ekstrak dari 10 jenis sponge memiliki daya hambat terhadap bakteri $P$. aeruginosa berkisar 2.03-27.74\%

Sensitifitas bakteri terhadap ekstrak dapat pula dipengaruhi oleh dinding selnya seperti adanya reseptor, pori dan kandungan lipid. Bakteri Gram positif lebih sensitif terhadap ekstrak non polar karena dinding selnya tersusun dari peptidoglikan, salah satunya adalah asam amino D-alanin yang bersifat hidrofobik. Bakteri Gram negatif memiliki lapisan tambahan pada dinding selnya yang tersusun dari lipopolisakarida, porin matriks dan lipoprotein. Adanya selaput khusus berupa molekul protein memudahkan difusi senyawa hidrofilik. Escherichia coli merupakan bakteri Gram negatif diduga sensitifitas terhadap ekstrak etanol dari $C$. gracilis menyebabkan enzim proteasenya dapat dihambat dengan mudah.
Perbedaan sisi aktif, berat molekul dan kestabilan enzim protease bakteri menyebabkan masing-masing ekstrak $C$. gracilis memiliki daya hambat yang berbeda-beda terhadap enzim protease bakteri patogen.

Hasil pengujian ekstrak C. gracilis sebagai inhibitor protease menunjukkan bahwa ekstrak dari $C$. gracilis yang dipanen pada umur 8 hari memiliki aktivitas penghambatan yang cukup baik terhadap protease bakteri uji. Chaetoceros gracilis yang dipanen pada umur 8 hari berada pada akhir fase log, kandungan protein pada biomassa selnya cukup tinggi sehingga diduga pada fase ini protein yang disekresikan memiliki efek inhibitor protease. Penelitian Nurhayati et al. (2006) mengenai inhibitor protease dari bakteri yang berasosiasi dengan spons menunjukkan bahwa selama waktu inkubasi inhibitor protease mencapai nilai maksimum, terjadi peningkatan konsentrasi protein sehingga diduga bahwa inhibitor protease adalah suatu protein.

Proses pembentukan senyawa aktif dalam tubuh mikroalga dipengaruhi oleh kondisi lingkungannya. Pada kultivasi $C$. gracilis di luar ruangan, baik intensitas cahaya maupun suhu kultivasi berubah-ubah. Meskipun intensitas cahaya dan suhu yang sampai masih dalam batas intensitas cahaya dan suhu pertumbuhan $C$. gracilis, namun perubahan intensitas cahaya dan suhu dari waktu ke waktu dapat menyebabkan kondisi yang kurang nyaman bagi $C$. gracilis. Berkaitan dengan hal ini Richmond (2004) menyatakan bahwa pada saat kondisi tidak nyaman atau mendekati stress, mikroalga melakukan respon fisiologis antara lain dengan memodifikasi genetik atau dengan mensintesis metabolit sekunder. Chaetoceros gracilis diduga merespon perubahan intensitas cahaya dan suhu dengan mensintesis senyawa metabolit diantaranya asam amino, alkaloid dan peptida yang diduga memiliki efek inhibitor protease. Kemampuan suatu inhibitor protease terhadap enzim protease dapat dipengaruhi oleh kesesuain sisi aktif, protein penyusun, berat molekul enzim protease, dan mekanisme penghambatan yang terjadi (Yandri, 2008).

Aktivitas inhibitor protease dari $\mathrm{C}$. gracilis berbeda dengan sponge. Nurhayati et al. (2004) melaporkan bahwa ekstrak sponge dengan pelarut akuades mempunyai potensi daya hambat erhadap E. coli dan S. Aureus berkisar antara 0.00$100.00 \%$.

\section{KESIMPULAN}

Pertumbuhan mikroalga Chaetoceros gracilis yang dikultivasi dalam media NPSi tidak jauh berbeda dengan yang dikultivasi dalam media NPSi+NaHCO 3 . Media NPSi dan $\mathrm{NPSi}+\mathrm{NaHCO}_{3}$ mempengaruhi kandungan protein dan lipid $\mathrm{C}$. gracilis. Kandungan protein $C$. gracilis yang dikultivasi dalam media NPSi lebih besar dibanding dalam media NPSi+NaHCO namun kadar lipidnya lebih rendah.

Eksktrak dari biomasa C. gracilis memiliki aktivitas penghambatan terhadap enzim protease bakteri patogen. Secara umum $C$. gracilis yang ditumbuhkan dalam media NPSi dan media NPSi+NaHCO 3 tidak menunjukkan perbedaan aktivitas inhibitor protease yang terlalu besar. Perbedaan media pertumbuhan $C$. gracilis yang digunakan tidak mempengaruhi 
aktivitas inhibitor proteaseterhadap E. coli. Aktivitas inhibitor protease terhadap bakteri $E$. coli lebih besar dibanding terhadap bakteri $B$. cereus dan $S$. aureus.

\section{UCAPAN TERIMA KASIH}

Penelitian ini dibantu dari penelitian Hibah Bersaing yang didanai DIKTI 2009/2010 dengan Nomor 28//3.24.4/SPK/BG$\mathrm{PD} / 2009$.

\section{DAFTAR PUSTAKA}

Elias JAL, Voltolina D, Ocana FE, Simental GG. 2005. Indoor and outdoor mass production of the diatom Chaetoceros muelleri in a Mexican commercial hatchery. J Aqua Eng 33: 181-191. DOI: 10.1016/j.aquaeng.2005.01.001.

Hui DY. 2003. HIV protease inhibitors and atherosclerosis. J Clin Invest 111:3 17-318. DOI: 10.1172/JCl17746.

Iverson SJ, Lang SL, Cooper MH. 2001. Comparison of the bligh and dyer and folch methods for total lipid determination in a broad range of marine tissue. Lipid 36: 1283-1287. DOI: 10.1007/s11745-001-0843-0.

Lehninger AL. 2005. Dasar-dasar Biokimia Jilid I. Suhartono MT, penerjemah. Penerbit Erlangga. Jakarta. Terjemahan dari Principles of Biochemistry,p. 382.

Nasaimento WCA, Martins MLL. 2004. Production and properties of an extracellular protease from thermophilic Bacillus sp. Brazilian J Microbiol 35: 91-96. DOI: 10.1590/ S1517-83822004000100015.

Nurhayati T, Suptijah P, Suhartono MT, Febrian I. 2004 Penapisan inhibitor protease yang dihasilkan oleh sponge asal Kepulauan Seribu. Bul Teknol Hasil Perikanan 8: 4558.
Nurhayati Y, Suhartono MT, Nuraida L, Poerwanto SB. 2006. Karakterisasi awal inhibitor protease dari bakteri yang berasosiasi dengan spons asal Pulau Panggang, Kepulauan Seribu. Hayati 13: 58-64.

Nurhayati T, Salamah E, Tampubolon K, Aprilan A. 2011 Peranan inhibitor katepsin dari ikan patin (Pangasius hypophthalmus) untuk menghambat kemunduran mutu ikan bandeng (Chanos chanos Forskal). J Pengolahan Hasil Perikanan Indonesia 17: 495-553.

Popowicz GM, Dubin G, Niemczyk JS, Czarny A, Dubin A Potempa J, Holak TA. 2006. Functional and structural characterization of $\mathrm{Spl}$ protease from Staphylococcus aureus. J Mol Biol 358: 270-279. DOI: 10.1016/j.jmb.2006. 01.098.

Pratiwi AR, Syah D, Hardjito L, Panggabean LMG, Suhartono MT. 2009. Fatty acid synthesis by Indonesian marine diatom, Chaetoceros gracilis. Hayati 16: 151-156. DOI: 10.4308/hjb.16.4.151.

Richmond A. 2004. Handbook of Microalgal Culture: biotechnology and applied phycologi. lowa State Press. Blackwell Publishing, p. 566.

Saavedra MPS, Voltolina D. 2006. The growth rate biomass production and composition of Chaetoceros sp. grown with different light sourch. J Aqua Eng 35: 161-165. DOI: 10.1016/j.aquaeng.2005.12.001.

Setyaningsih I, Hardjito L, Monintja DR, Sondita MFA, Bintang M, Lailati N, Panggabean L. 2008. Ekstraksi senyawa antibakteri dari diatom Chaetoceros gracilis dengan berbagai metode. J Biol Indo 5: 23-33.

Voltolina D, Saavedra MPS, Rodriguez LMT 2007. Outdoor mass microalgae production in bahia kino, Sonora, New Mexico. J Aqua Eng 38: 96-96.

Yandri, Tati S, Dian H, Sutopo H. 2008. The chemical modification of protease enzyme isolated from locale bacteria isolate, Bacillus subtilis ITBCCB148 with cyanuric chloride-polyethylenglycol. J Sci Res 23: 177-186. 